\title{
PERBANDINGAN PRODUKTIVITAS KERJA SALES SEBELUM DAN SESUDAH PELATIHAN PADA AUTO 2000 RADEN INTAN BANDAR LAMPUNG
}

\author{
Dewi Ferawati $\left({ }^{1}\right)$, Suwandi $\left({ }^{2}\right)$ \\ Institut Informatika Dan Bisnis Darmajaya \\ dewiferawati@gmail.com,suwandi@darmajaya.ac.id
}

\begin{abstract}
Abstrak. Tujuan dilakukanya penelitan ini adalah untuk mengetahui perbedaan produktivitas kerja sales sebelum dan sesudah pelatihan pada Auto 2000 Raden Intan Bandar Lampung. Permasalahan yang muncul dalam penelitian ini adalah menurunya produktivitas kerja sales di sebabkan oleh kurangnya pengetahuan tentang produk dan skill negosiasi lemah. Populasi dalam penelitian ini adalah seluruh sales yang ada di auto 2000 Raden Intan Bandar Lampung yang berjumlah 52 orang. Teknik sampling yang digunakan adalah sampling jenuh. Dengan demikian sampel dalam penelitian ini berjumlah 52 orang. Metode analisis data yang yang digunakan Uji Paired sample $t$ test. Hasil pengujian hipotesis yang dilakukan menunjukan terdapat perbedaan produktivitas kerja sales sebelum dan sesudah pelatihan. Produktivitas kerja sales sesudah mengikuti pelatihan dinilai lebih baik. Dibandingkan dengan produktivitas kerja sales sebelum mengikuti pelatihan. Hasil penelitian menunjukan produktivitas kerja sales sesudah mengikuti pelatihan dinilai lebih baik dibandingkan dengan sebelum mengikuti pelatihan pada Auto 2000 Raden Intan Bandar Lampung.
\end{abstract}

Kata Kunci. Produktivitas Kerja Sales Sebelum dan Sesudah Pelatih.

Abstract. The purpose of this research is to determine the difference in sales work productivity before and after training at Auto 2000 Radenlntan Bandar Lampung. The problem that arises in this study is that the decline in sales work productivity is caused by a lack of knowledge about products and weak negotiation skills. The population in this study were all sales in auto 2000 Radenlntan Bandar Lampung, which numbered 52 people. The sampling technique used is saturated sampling. Thus the sample in this study amounted to 52 people. The data analysis method used is the Paired sample t test. The results of hypothesis testing conducted show there are differences in sales work productivity before and after training. Productivity of sales work after training is considered better. Compared with sales work productivity before attending training. The results showed that the work productivity of sales after training was considered better than before training at Auto 2000 Radenlntan Bandar Lampung.

Keywords. Productivity of Sales Work Before and After Training.

\section{PENDAHULUAN}

Keberhasilan suatu organisasi bergantung pada produktivitas yang dimiliki baik secara perorangan ataupun tim didalam organisasi tersebut. Produktivitas merupakan perbandingan antara keluaran dan masukan serta mengatakan cara pemanfaatan baik terhadap sumber-sumber dalam memproduksi suatu barang atau jasa (Raharjo et al., 2016). Dari pemahaman diatas dapat diartikan bahwa produktivitas menyentuh berbagai aspek dalam diri manusia seperti sikap, mental, etika dan keahlian sehingga dapat dijadikan sebagai pendorong dalam meningkatkan mutu untuk menjadi lebih baik setiap harinya. Produktivitas merupakan faktor yang sangat penting untuk kelangsungan perusahaan karena merupakan faktor kunci untuk dapat melakukan perbaikan setiap hari dan hanya tenaga kerja yang dapat meningkatkan produktivitas. Menurut Sutrisno produktivitas merupakan output per 
unit, atau output dibagi input, atau rasio antara output dengan input (Sutrisno, 2011).

Berdasarkan hasil wawancara pada salah satu supervisor sales pada Auto 2000 Raden Intan Bandar Lampung yaitu, bapak Muhamad Nurhadi Wijaya produktivitas kerja sales yang terjadi pada Auto 2000 Raden Intan Bandar Lampung sebelum sampai denga sesudah diadakanya pelatihan mengalami penurunan karena belum bisa memenuhi target yang di tetapkan oleh perusahaan faktor yang menyebabkan menurunnya produktivitas kerja yang terjadi di Auto 2000 Raden Intan Bandar Lampung terdapat 2 (dua) faktor yang dapat mempengaruhi produktivitas kerja sales tidak dapat mencapai target penjualan, yang pertama sales tidak mendapatkan order SPK (Surat Pesana Kendaraan) dikarenakan kurangnya pengetahuan tentang produk, skill negosiasi lemah, pasif, pengalaman, masa kerja, masalah pribadi, kerja tidak maksimal. Dan yang kedua adalah sales mendapatkan order SPK (Surat Pesanan Kendaraan) Nmun tidak jadi DO (Drop Out) dikarenakan riject leasing, unit yang di pesan oleh customer tidak ada, dana customer terpakai, trade in penjualan tidak laku serta melihat banyaknya sales yang perlu diikutsertakan dalam pelatihan kerja ada kendala yang harus di pertimbangkan karena pelatihan tidak diadakan di Bandar Lampung melainkan pelatihan kerja sales di adakan di Jakarta dan jumlah peserta pelatihan di tentukan oleh Auto 2000 pusat.

Untuk meningkatkan produktivitas penjualan secara maksimal tentunya seorang sales di tuntut untuk menguasai tugasnya dengan baik dan benar agar dapat tercapai target penjualan sebagaimana yang telah ditetapkan oleh perusahaan dalam jangka waktu tertentu. Adapun tugas seorang sales yaitu, aktif menjual produk agar dapat mencapai target, merekap data hasil penjualan, menjamin kepuasan pelanggan, mencari mitra kerja, dan yang terakhir adalah menyusun strategi lanjutan bila strategi yang dianjurkan perusahaan tidak dapat memenuhi target. Berikut adalah jumlah target yang harus di capai sales dala jangka waktu tertentu berdasarkan golongan sales.

Tabel 1

Target Penjualan Salaes Berdasarkan

Golongan Pada Auto 2000 Raden Intan Bandar Lampung

\begin{tabular}{lll}
\hline NO & Golongan Sales & $\begin{array}{l}\text { Target Penjualan } \\
\text { perbulan }\end{array}$ \\
\hline $\mathbf{1}$ & Counter (CTR ) & $\mathbf{1 0}$ \\
$\mathbf{2}$ & Sales Asisten (SAS) & $\mathbf{2}$ \\
$\mathbf{3}$ & $\begin{array}{l}\text { Junior Sales Executive } \\
\text { (JSE) }\end{array}$ & $\mathbf{3}$ \\
$\mathbf{4}$ & $\begin{array}{l}\text { Sales Executive (SE) } \\
\mathbf{5}\end{array}$ & $\mathbf{4}$ \\
& $\begin{array}{l}\text { Senior Sales Executive } \\
\text { (SSE) }\end{array}$ & $\mathbf{8}$ \\
\hline Total & & $\mathbf{2 7}$ \\
\hline & Tahmber: & Auto 2000 Raden Intan Bandar Lampung 2019
\end{tabular}

Tabel 1.1 diatas menunjukan tingkat target penuajalan sales berdasarkan golonganya pada Auto 2000 Raden Intan Bandar Lampung. Dimana Counter (CTR) di beri target untuk menjual 10 produk perbulan, Sales Asisten (SAS) di beri target untuk menjual 2 produk perbulan, JSE diberi target untuk menjual 3 produk perbulan, SE diberi target untuk menjual 4 produk perbulan, dan SSE diberi target untuk menjual 8 produk perbulan. Setiap sales diberikan target penjualan yang berbeda, semakin tinggi golongan sales tersebut maka semakin tinggi pula target yang diberikan oleh perusahaan. Masing-masing golongan sales dituntut untuk bisa mencapai target yang telah di berikan oleh perusahaan dalam jangka waktu tertentu 
guna mencapai tujuan perusahaan untuk memperoleh pendapatan secara maksimal. Agar mampu meningkatkan produktivitas kerja karyawan dan menghasilkan tenaga-tenaga marketing yang terampil dan professional. Peningkatan produktivitas kerja sales membutuhkan manajemen yang baik dalam memaksimalkan hasil yang dicapai dengan kemampuan dasar manusia melalui pembagian tugas dan tanggung jawab yang akan membentuk kerja sama dalam organisasi. Keberhasilan suatu organisasi bergantung pada produktivitas yang dihasilkan baik secara perorangan ataupun tim didalam organisasi tersebut. Pengembangan karyawan dirasakan semakin penting manfaatnya karena tuntutan pekerjaan dalam pencapaian target yang telah ditetapkan perusahaan, sebagai akibat perkembangan pasar yang terus miningkat dan semakin ketatnya persaingan diantara perusahaan yang sejenis.

Menurut Wungu dan Brotoharsojo, (2003) pelatihan pegawai atau training adalah upaya sistematik perusahaan untuk meningkatkan segenap pengetahuan (knowledge), ketrampilan (skill) dan sikap-sikap kerja (attitudes) para karyawan melalui proses belajar agar optimal dalam menjalankan fungsi dan tugas-tugas jabatannya. Program pelatihan yang diselenggarakan secara intensif oleh perusahaan akan membuat karyawan lebih banyak menyerap ilmu, informasi, serta mengasah keahlian. Hal ini dapat membuat kecenderungan karyawan untuk lebih giat bekerja karena dalam penyelesaian pekerjaannya dirasa lebih mudah. Menurut Hariawati (2009) fungsi latihan kerja yang ideal bertujuan memberikan cara dan kesempatan kepada semua pekerja untuk menyesuaikan diri dengan puas terhadap tuntutan bisnis dan operasi-operasi industri sejak hari pertama masuk bekerja, kekuatan produktif ditandai dengan perolehan kemajuan perusahaan dengan jalan mengembangkan secara rutin kebutuhan ketrampilan, pengetahuan dan sikap. Pelatihan sangat penting untuk dilaksanakan bagi kepentingan bersama, sebab dari sinilah para karyawan akan dapat lebih memahami dan mengerti tentang tugas dan tanggung jawab yang diemban baik secara individu maupun kelompok. Kaswan (2011) mengatakan beberapa indikator dalam pelatihan, sebagai berikut: identifikasi, motivasi, lingkungan pembelajaran, penerapan, metode dan hasil Berikut adalah data pelatihan yang diikuti oleh sales Auto 2000 Raden Intan Bandar Lampung:

Tabel 2

Jenis Pelatihan

\begin{tabular}{|c|c|c|c|c|}
\hline Tahun & Jenis Pelatihan & $\begin{array}{l}\text { Belum } \\
\text { Mengik } \\
\text { uti } \\
\text { Pelatih } \\
\text { an }\end{array}$ & $\begin{array}{l}\text { Sudah } \\
\text { Mengik } \\
\text { uti } \\
\text { Pelatiha } \\
\text { n }\end{array}$ & $\begin{array}{l}\text { Juml } \\
\text { ah } \\
\text { Sales }\end{array}$ \\
\hline & $\begin{array}{l}\text { Fundamental } \\
\text { Sales } \\
\text { Training } \\
\text { (FST) }\end{array}$ & 0 & 52 & 52 \\
\hline \multicolumn{5}{|l|}{2018} \\
\hline & $\begin{array}{l}\text { Profesional } \\
\text { Salesman } \\
\text { Skill Training } \\
\text { (PSST) }\end{array}$ & 16 & 36 & 52 \\
\hline & $\begin{array}{l}\text { Advance } \\
\text { Selling Skill } \\
\text { Training } \\
\text { (ASST) }\end{array}$ & 21 & 31 & 52 \\
\hline
\end{tabular}

Sumber: Auto 2000 Raden Intan Bandar Lampung tahun 2018.

Berdasarkan data pelatihan Tabel 1.2 dapat dilihat bahwa 31 sales telah mengikuti Advance Selling Skill Training (ASST) dan bagi sales yang belum mengikuti Advance Selling Skill Training dipastikan telah mengikuti pelatihan sebelumnya yaitu 
Profesional Salesman Skill Training (PSST) dan Fundamental Sales Training (FST) jadi, seluruh sales yang ada di Auto 2000 Raden Intan Bandar Lampung telah mengikuti pelatihan yang di adakam oleh perusahaan. Diadakanya pelatihan kerja guna untuk meningkatkan produktivitas kerjanya dan menghasilkan tenaga-tenaga marketing yang terampil dan professional. Pengembangan karyawan dirasakan semakin penting manfaatnya karena tuntutan pekerjaan, sebagai akibat kemajuan teknlogi dan semakin ketatnya persaingan diantara perusahaan yang sejenis.

Permasalahan dalam penelitian ini yaitu, Apakah terdapat perbedaan Produktivitas Kerja Sales Sebelum Dan Sesudah Pelatihan Pada Auto 2000 Raden Intan Bandar Lampung?.

Menurut Bandura self-efficacy adalah persepsi diri sendiri mengenai seberapa bagus diri dapat berfungsi dalam situasi tertentu. Self-efficacy berhubungan dengan keyakinan diri memiliki kemampuan melakukan tindakan yang diharapkan. Selfefficacy adalah penilaian diri, apakah dapat melakukan tindakan yang baik atau buruk, tepat atau salah, bisa atau tidak bisa mengerjakan sesuai dengan yang dipersyaratkan.Self-efficacy menggambarkan penilaian kemampuan diri. Bandura (2001) mendefinisikan self-efficacy sebagai keyakinan manusia pada kemampuan mereka untuk melatih sejumlah ukuran pengendalian terhadap fungsi diri mereka dan kejadian-kejadian di lingkunganya.

Meningkatkan kemampuan dirimelalui penerapan bakat secara berhasil Menurut McClelland karakteristik orang yang berprestasi tinggi (high achievers) memiliki tiga ciri umum yaitu :(1) sebuah preferensi untuk mengerjakan tugas-tugas dengan derajat kesulitan moderat; (2) menyukai situasi-situasi di mana kinerja mereka timbul karena upaya-upaya mereka sendiri, dan bukan karena faktor-faktor lain,seperti kemujuran misalnya; dan (3) menginginkan umpan balik tentang keberhasilan dan kegagalan mereka,dibandingkan dengan mereka yang berprestasi rendah.

Menurut Sutrisno (2011) produktivitas merupakan output per unit, atau output dibagi input, atau rasio antara output dengan input. Whitmore (Sedarmayanti, 2005) Produktivitas adalah kemampuan memperoleh manfaat sebesar- besarnya dari sarana dan prasarana yang tersedia dengan menghasilkan (output) yang optimal bahkan kalau mungkin yang maksimal, Siagian (2006). Triton (2007) mendefinisikan bahwa produktivitas kerja sebagai perbandingan hasil-hasil yang dicapai dengan keseluruhan sumber daya yang dipergunakan atau perbandingan jumlah produksi (output) dengan sumber daya yang digunakan (input). Hasibuan (2005) mendefinisikan produktivitas kerja adalah perbandingan antara output dengan input, di mana outputnya harus mempunyai nilai tambah dan teknik pengerjaannya yang lebih baik.

Menurut Ivancevich dalam Sutrisno (2009) pelatihan didefinisikan sebagai usaha untuk meningkatkan kinerja karyawan dalam pekerjaannya sekarang atau dalam pekerjaan lain yang akan dijabatnya segera. Pelatihan terkait dengan ketrampilan dan kemampuan yang diperlukan untuk pekerjaan yang sekarang dilakukan. Pelatihan berorientasi ke masa sekarang dan membantu karyawan untuk menguasai ketrampilan dalam pekerjaanya. Menurut Wibowo (2014) pelatihan (training) dan pengembangan (development) adalah merupakan investasi organisasi yang penting dalam sumber daya manusia. Pelatihan melibatkan segenap sumber daya 
manusia untuk mendapatkan pengetahuan dan ketrampilan pembelajaran sehingga mereka segera akan dapat mengguakanya dalam pekerjaan. Pada dasarnya, pelatihan diperlukan karena adanya kesenjangan antara ketrampilan pekerja sekarang dengan ketrampilanl yang dinutuhkan untuk menempati posisi baru. Menurut Melayu S.P Hasibuan (2016) metode latihan harus berdasarkan kepada kebutuhan pekerjaan tergantung pada berbagai faktor, yaitu, waktu, biaya, jumlah peserta, tingkat pendidikan dasar peserta, latar belakang peserta, dan lain-lain.

Metode-metode latihan menurut Sikula dalam Hasibuan (2016), yauitu: a) On the Job Para peserta latihan langsung bekerja ditempat untuk belajar dan meniru suatu pekerjaan dibawah bimbingan seorang pengawas. Metode latihan dibedakan dalam 2 cara, yaitu: 1. Cara informal yaitu pelatihan menyuruh peserta pelatihan untuk memperhatikan orang lain yang sedang nelakukan pekerjaaan, kemudian diperintahkan utnuk mempraktekanya; 2. Cara formal yaitu supervisor menunjuk karyawan senior untuk melakukan pekerjaan tersebut, selanjutnya para peserta latihan melakukan pekerjaan yang sesuai dengan cara-cara yang dilakukan karyawan senior. On the Job Training dapat pula latihan dengan dilakukan dengan menggunakan bagan, gambar, pedoman, contoh yang sederhana, demonstrasi, dan lain-lain. Kebaikan cara on the job training ini ialah para peserta belajar langsung pada kenyataan pekerjaan dan peralatan. Adapun keburukanya adalah pelaksanaan sering tidak teratur (tidak sistematis) dan kurang efektif jika pengawas kurang pengalaman. $b$ ) Vestibule adalah metode latohan yang dilakukan dalam kelas atau bengkel yag biasanya diselenggarakan dalam suatu perusahaan intdustri untuk memperkenalkan pekerjaan kepada karyawan baru dan melatih mereka mengerjakan pekerjaan tersebut. Melalui percobaan dibuat suatu duplikat dari bahan, alat-alat, dan kondisi yang akan mereka temui dalam situasi kerja yang sebenarnya; c) Demonstrasion and Example: Demonstrasion and Example adalah metode latihan yang dilakukan dengan cara peragaan dan penjelasan bagaimana cara-cara mengerjakan sesuatu pekerjaan melalui contoh-contoh atau percobaan yang didemonstarsikan; d) Simulation merupakan suatu situasi atau kejadian yang ditampilkan semirip mungkin dengan situasi yang sebenarnya tapi hanya merupakan suatu teknik untuk mencontoh semirip mungkin terhadap konsep sebenarnya dari pekerjaan yang akan dijumpainya; e) Apprenticeship: Metode ini adalah suatu cara untuk mengembangkan keahlian pertukangan sehingga para karyawan yang bersangkutan dapat mempelajari segala aspek dari pekerjaanya; f) Classroom Methods: Metode pertemuan dalam kelas meliputi lecture (pelajaran), conference (rapat), programmed instruction, metode studi kasus, role playing, metode diskusi dan metode seminar.

Menurut Faustini Cardoso Gomes (2000), indikator efektivitas suatu pelatihan dapat dievaluasi berdasarkan informasi yang diperoleh sebagai berikut: (1) Reaksi, yaitu untuk mengetahui opini dari para peserta mengenai program pelatihan, pada akhir pelatihan para peserta ditanya mengenai seberapa jauh mereka puas terhadap pelatihan secara keseluruhan, terhadap pelatih/instruktur, materi yang disampaikan, isinya, bahan-bahan yang disediakan, dan lingkungan pelatihan (ruangan, waktu 
istirahat, makanan, suhu udara); (2) Pembelajaran, yaitu untuk mengetahui seberapa jauh para peserta menguasai kensep-konsep, pengetahuan dan keterampilan-keterampilan yang diberikan selama pelatihan. Biasanya dilakukan dengan mengadakan test tertulis (essay atau multiple choice), test performansi dan latihanlatihan simulasi; (3) Perilaku, menilai dari para peserta sebelum dan sesudah pelatihan, dapat dibandingkan guna mengetahui tingkat pengaruh pelatihan terhadap perubahan peformansi mereka; (4) Hasil, yaitu utuk menguji dampak pelatihan terhadap kelompok kerja atau organisasi secara keseluruhan. Data bisa dikumpulkan sebelum dan sesudah pelatihan atas dasar kriteria produktivitas, pergantian, absen, kecelakaan-kecelakaan, keluhan-keluhan, perbaikan kualitas, kepuasan klien dan sejenis lainnya.

Tiga (3) penelitian terdahulu yang ada dalam penelitian ini yaitu (1) analisis produktivitas Kerja Karyawan ditinjau dari Tingkat Pendidikan Kompensasi; Hasil penelitian ini menunjukan bahwa ada perbedaan produktivitas kerja karyawan ditinjau dari tingkat pendidikan karyawan (Novita, 2017); (2) Perbedaan Produktivitas Kerja Guru Antara Yang Sudah Dan Belum Sertifikasi Pada Sekolah Pertama (SMP) Malang; Hasil dari penelitian ini menunjukkan bahwa tidak terdapat perbedaan produktivitas kerja guru antara yang sudah dan belum sertifikasi (Fitirna, 2017); (3) Analisis Perbedaan Produktivitas kerja karyawan sebelum dan sesudah pelatihan pada PT. Bank Rakyat Indonesia, Tbk Kantor Cabang Serui; Hasil penelitian menunjukkan bahwa ada perbedaan Produktivitas kerja karyawan sebelum dan sesudah pelatihan sebesar 3,176 dengan tingkat signifikansi 0,019 (Nasution, 2018).
Hipotesis dalam penelitina adalah $\mathrm{H}_{1}$ : Terdapat perbedaan produktivias antara sebelum dan sesudah pelatihan.

\section{METODOLOGI}

Jenis Penelitian adalah suatu proses pengumpulan dan analisis yang dilakukan secara sistematis dan logis untuk tujuan tertentu. Peneliti ini menggunakan jenis penelitian Kuantitatif. Dalam penelitian ini, penulis menggunakan hipotesis Komparatif yang menurut (Sugiyono, 2017) merupakan jawaban sementara terhadap rumusan masalah Komparatif. Pada rumusan Komparatif ini, variabelnya sama tetapi populasi atau sampelnya yang berbeda, atau keadaan itu terjadi pada waktu yang berbeda. Menurut Suliyanto (2018) penelitian komparatif adalah penelitian yang membandingkan dari sampel yang satu dengan sampel yang lain baik sampel bebas maupun sampel yang berpasangan, ini digunakan untuk mengetahui perbandingan Produktivitas Kerja Sales Sebelum dan Sesudah Pelatihan pada Auto 2000 Raden Intan Bandar Lampung.

Untuk mengakui keberadaan hipotesis yang dikemukakan sebelumnya, maka sumber data yang di gunakan dalam penulisan skripsi ini adalah : (1) Data Primer menurut Anwar Sanusi (2017), data primer merupakan data yang pertama kali dicatat dan dikumpulkan oleh peneliti. Dalam hal ini penuli menggunakan data primer berupa wawancara dan kuisioner yang di ambil langsung di Auto 2000 Raden Intan Bandar Lampung; (2) Data Sekunder menurut Anwar Sanusi (2017), data sekunder merupakan data yang sudah tersedia dan dikumpulkan oleh pihak lain. Data sekunder yang digunakan berupa jurnal-jurnal penelitian terdahulu, buku-buku yang 
berhubungan dengan Pelatihan dan Produktivitas Kerja Sales.

Menurut Sugiyono (2013) metode pengumpulan data dilakukan dengan cara mengadakan peninjauan pada instansi yang menjadi objek untuk mendapatkan data primer dan skunder. Adapun metode pengumpulan data yang dilakukan oleh penulis diantanya sebagai berikut: (1) Penelitian Keperpustakaan (Library Research) menurut Suliyanto (2018) Penelitian keperpustakaan merupakan penelitian yang dilakukan dengan menggunakan bahan-bahan karya tulis atau bahan keperpustakaan (literature) termasuk penelitian yang sebelumnya; (2) Penelitian Lapangan(Field Research) yaitu pengupulan data dengan langsung terjun (survei) pada perusahaan yang menjadi objek-objek penelitian. Untuk memperoleh data primer dari perusahaan, maka cara yang dilakukan adalah : (a) Wawancara menurut Anwar Sanusi (2017) wawancara merupakan teknik pengumpulan data yang menggunakan pertanyaan secara lisan kepada subjek penelitian. Wawancara dilakukan dengan supervisor sales pada Auto 2000 Raden Intan Bandar Lampung; (b) Kuisioner menurut Anwar Sanusi (2017), kuisioner data yang sering tidak memerlukan kehadiran peneliti, namun cukup diwakili oleh daftar pertanyaan yang sedah disusun secara cermat dahulu. Dalam hal ini respondennya adalah Auto 2000 Raden Intan Bandar Lampung.

Menurut Suliyanto (2018), populasi merupakan keseluruhan elemen yang yang hendak diduga karakteristiknya. Maka populasi dalam penelitian ini adalah 52 jumlah keseluruhan sales yang ada pada Auto 2000 Raden Intan Badar Lampung.

Pengambilan sampel menggunakan non probability sampling yaitu teknik pengambilan sampel dimana tiap anggota populasi tidak mempunyai peluang yang sama untuk dijadikan sampel (Suliyanto 2018) dengan menggunakan teknik sampling jenuh yaitu teknik penentuan sampel apabila semua anggota populasi digunakan sebagai sampel (sugiyono 2016) jumlah sampel dalam penelitian ini adalah jumlah keseluruhan sales yang berjumlah 52 orang sales yang ada di Auto 2000 Raden Intan Bandar Lampung.

Menurut Suliyanto (2018), variabel penelitian adalah suatu yang dikarakteristikan atau nilainya berubah-ubah, berbeda-beda, atau bermacam- macam. Dalam penelitian ini yang menjadi variabel adalah produktivitas kerja sales Auto 2000 Raden Intan Bandar Lampung.

Menurut Suliyanto (2018) validitas instrumen adalah tingkat ketepatan dan kecermatan suatu alat ukur yang melakukan fungsi ukurannya. ditentukan dengan mengkorelasikan antara skor yang diperoleh setiap butir pertanyaan atau pernyataan dari skor total. Pada program SPSS teknik pengujian yang sering digunakan untuk uji validitas adalah menggunakan korelasi Bivariate Pearson (Produk Momen Pearson) diolah menggunakan program spss 20 dengan kriteria sebagai berikut: Menentukan nilai probabilitas (sig) pada $\alpha$ sebesar 0,05 (5\%); (1) Bila Sig> Alpha $(0,5)$ maka instrumen tidak valid; Bila Sig< Alpha $(0,5)$ maka instrumen valid; (2) Pengujian validitas instrumen dilakukan melalui program SPSS (Statistical Program and Service Solution seri 20); (3) Kuisioner dinyatakan valid apabila nilsi koefisien korelasi lebih besar dari pada nilai korelasi yang tercantum dalam tabel pada $\alpha=5 \%$. 
Menurut Suliyanto (2018) uji reliabilitas digunakan untuk menunjukkan kemampuan alat ukur untuk menghasilkan hasil pengukuran yang dapat dipercaya (Aryani \& Rosinta, 2010). Hasil pengukuran dapat dipercaya apabila dalam beberapa kali pelaksanaan pengukuran terhadap kelompok objek yang sama diperoleh hasil yang relative sama Uji reliabilitas dilakukan dengan menggunakan teknik Cronbach'sAlpha. menggunakan computer program SPSS for windows dengan tingkat signifikansi 0,05. Uji normalitas sampel digunakan untuk mengetahui apakah jumlah sampel yang diambil sudah refresentatif atau belum, sehingga kesimpulan penelitian yang diambil dari jumlah sampel bisa dipertanggungjawabkan. Uji normalitas pada penelitian ini penulis menggunakan bantuan program spss versi 20 . Kriteria pengambilan keputusan: Apabila Sig < 0.05 maka Ho ditolak (distribusi sampel tidak normal); Apabila Sig > 0.05 maka Ho diterima (distribusi sampel normal).

Untuk mendapatkan hasil yang sesuai dengan tujuan penelitian,maka diperlukan metode analisis data yang benar. Pengujian dilakukan dengan menggunakan bantuan Software SPSS. Adapun teknik analisis data dalam penelitian ini menggungakan uji beda t-test (Paired sample test). Yang mana uji beda untuk mengetahui perbedaan produktivitas kerja sales sebelum dan sesudah pelatihan pada Auto 2000 Raden Intan Bandar Lampung.

Paired sample t-test adalah pengujian yang dilakukan terhadap dua sampel yang berpasangan. Menurut Suliyanto (2018) Sampel yang berpasangan dapat diartikan sebagai sampel dengan subjek yang sama namun mengalami dua atau perlakuan yang berbeda. Misalnya dalam penelitian ini membandingkan antara produktivitas kerja sales sebelum pelatihan dan produktivitas kerja sales sesudah pelatihan. Disini subjeknya sama tetapi mengalami perlakuan yang berbeda yaitu sebelum pelatihan dan sesudah pelatihan. Cara analisis data menggunakan SPSS 20 dengan tingkat signifikan 0.05. Kriteria Pengujian: Ho: tidak dapat ditolak jika : $t_{\text {hitung }} \leq \mathrm{t}_{\text {tabel }}$ atau Sig $>$ 0,05; Ha: diterima jika: $t_{\text {hitung }}>t_{\text {tabel }}$ atau Sig $\leq 0,05$.

Hipotesis pada penelitian ini menggunakan uji paired sample t-test pada penelitian ini mengenai perbandingan produktivitas kerja sales sebelum dan sesudah pelatihan dalam perhitungan menggunakan bantuan program SPSS versi 20. uji paired sample t-test digunakan untuk menguji signifikansi dan untuk membandingkan selisih dua mean dari dua sampel yang berpasangan, uji paired sample t-test ini menggunakan tingkat kepercayaan $95 \%(a=5 \%)$ dan derajat bebas $/ \mathrm{dk}=\mathrm{n}-1$, dengan penentuan penerimaan atau penolakan hipotesis sebagai berikut: Ho = Tidak ada perbedaan produktivitas kerja sales sebelum dan sesudah pelatihan pada Auto 2000 Raden Intan Bandar Lampung; $\mathrm{Ha}=\quad$ Ada perbedaan produktivitas kerja sales sebelum dan sesudah pelatihan pada Auto 2000 Raden Bandar Lampung. Kriteria Pengambilan Keputusan: (1) Apabila sig $<0.05$ atau $t$ hitung > t tabel maka Ho ditolak; (2) Apabila sig $>0.05$ atau $t$ hitung $<\mathrm{t}$ tabel maka Ho diterima.

\section{HASIL DAN PEMBAHASAN} HASIL

Uji validitas dilakukan dengan menggunakan kolerasi product moment.Uji validtas ini dilakukan dengan menggunakan aplikasi SPSS 20.0 . Kriteria pengujian untuk uji validitas ini adalah: Bila probabilitas (sig) $<0,05$ maka instrument valid; Bila 
probabilitas ( $\mathrm{sig}$ ) > 0,05 maka instrument tidak valid. Berdasarkan hasil pengolahan data diperoleh data sebagai berikut: hasil uji validitas variabel sebelum pelatihan dengan menampilkan seluruh item pernyataan yang bersangkutan mengenai sebelum pelatihan.Hasil yang didapatkan yaitu nilai sig < alpha $(0,05)$. Dengan demikian seluruh item pernyataan mengenai sebelum pelatihan dinyatakan valid, sedangkan hasil uji validitas variabel setelah pelatihan dengan menampilkan seluruh item pernyataan yang bersangkutan mengenai sesudah pelatihan. Hasil yang didapatkan yaitu nilaisig < alpha $(0,05)$. Dengan demikian seluruh item pernyataan mengenai sesudah pelatihan dinyatakan valid.

Tabel 3

Hasil Uji Reliabitas

\begin{tabular}{lcl}
\hline Variabel & $\begin{array}{c}\text { Nilai } \\
\text { Alpha } \\
\text { Cronbach }\end{array}$ & Keterangan \\
Sebelum & & \\
Pelatihan & & Sangat \\
Sesudah &, & Tinggi \\
Pelatihan & 9 & \\
& 0 & Sangat \\
&, & Tinggi \\
\hline
\end{tabular}

Sumber : Hasil data diolah tahun 2019.

Berdasarkan tabel di atas hasil uji reliabilitas dengan nilai tertinggi adalah Sebelum Pelatihan sebesar 0,944 dan nilai reliabilitas terendah adalah Sesudah Pelatihan sebesar 0.919.

Uji normalitas dalam penelitian ini menggunakan uji one sample Kolmogorov-Smirnov Test pada program SPSS 24. Dalam uji normalitas dilakukan dengan melihat tingkat signifikan: Jika sig > 0.05, maka data tersebut berdistribusi secara normal; Jika sig < 0.05, maka data tersebut tidak berdistribusi secara normal; berikut ini merupakan hasil uji one sample Kolmogorof-Smirnov yaitu diperoleh hasil:

Tabel 4

Hasil Uji Normalitas

\begin{tabular}{llllc}
\multicolumn{1}{c}{ Variabel } & $\begin{array}{c}\text { Si } \\
\text { g }\end{array}$ & $\begin{array}{c}\text { Al } \\
\text { pha }\end{array}$ & $\begin{array}{c}\text { Kriteri } \\
\text { a }\end{array}$ & $\begin{array}{c}\text { Keteran } \\
\text { gan }\end{array}$ \\
Produktivitas_Se & 0, & 0,0 & Sig $>$ & Normal \\
belum & 40 & 5 & 0,05 & \\
& 6 & & & \\
Produktivitas_Se & 0, & 0,0 & Sig $>$ & Normal \\
sudah & 87 & 5 & 0,05 & \\
& 9 & & &
\end{tabular}

Sumber : Hasil data diolah tahun 2019

Berdasarkan tabel di atas menunjukkan bahwa nilai signifikansi sebelum dan sesudah pelatihan. Produktivitas Kerja > 0,05 yang berarti menyatakan bahwa data tersebut berdistribusi normal.

Tabel 5

Hasil Uji Paired Sample t-test

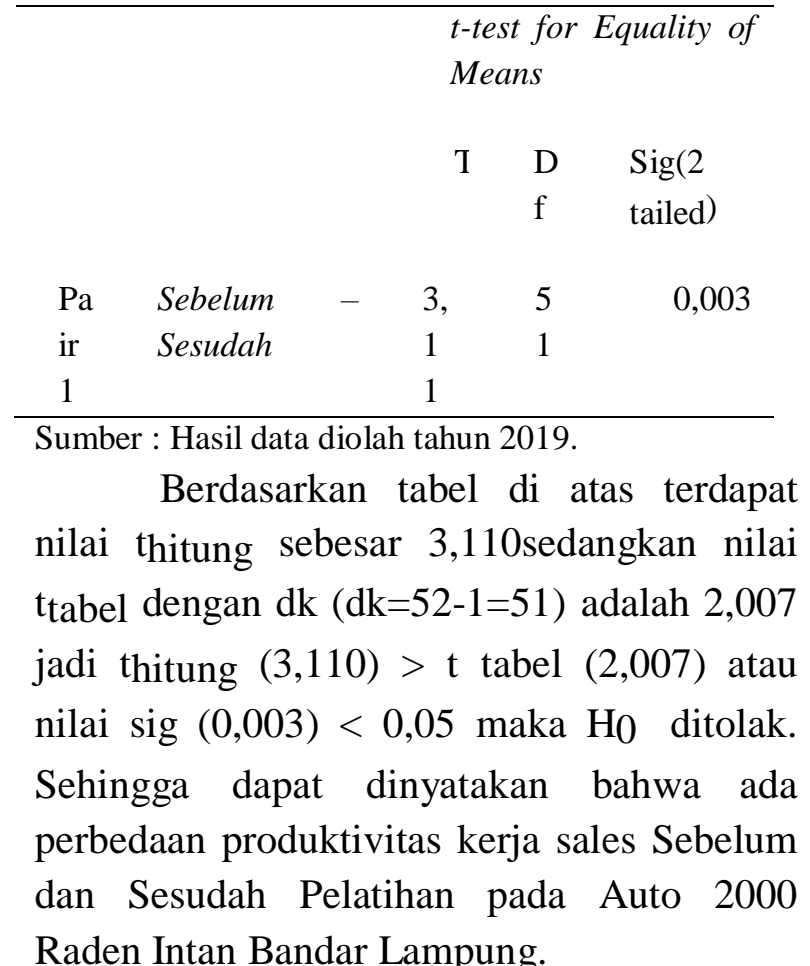

Raden Intan Bandar Lampung. 


\section{Hasil Group Statistics}

\section{Paired Samples Statistics}

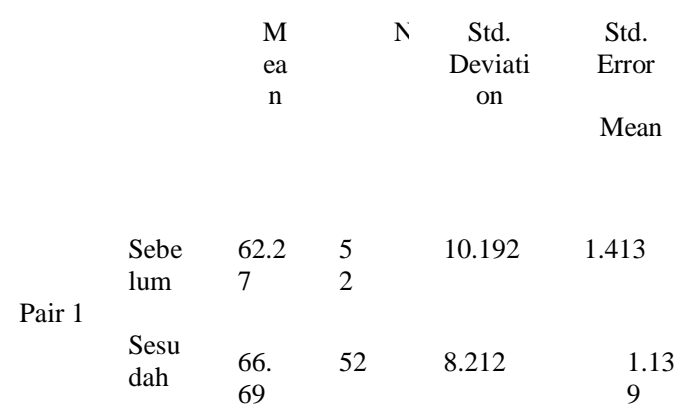

Sumber : Data diolah tahun 2019

Berdasarkan tabel di atas menunjukan bahwa produktivitas kerja dari 52 orang karyawan perusahaan, rata- rata produktivitas kerja sales sebelum pelatihan sebesar 62,27 masuk kedalam kategori cukup baik karena berada di interval 53.92-70.61. Jika di bandingkan dengan rata- rata produktivitas kerja sales sesudah pelatihan sebesar 66,69 masuk kedalam kategori cukup baik karena berada di interval 58.02-75.80.

\section{PEMBAHASAN}

Hasil Penelitian ini menunjukkan bahwa ada perbedaan produktivitas kerja karyawan sebelum dan sesudah pelatihan. Setelah diberikan pelatihan kerja produktivitas kerja karyawan semakin membaik dikarenakan pengetahuan serta kemampuan karyawan meningkat. Perbedaan produktivitas kerja karyawan sebelum dan sesudah pelatihan terlihat dari rata-rata skor total produktivitas kerja yang menunjukkan bahwa produktivitas kerja sesudah mengikuti pelatihan mengalami peningkatan yang cukup baik jika dibandingkan dengan produktivitas kerja sebelum mengikuti pelatihan. Hal ini menjelaskan bahwa karyawan yang sudah mengikuti pelatihan dapat menerapkan pengetahuan atau hasil yang didapatkan saat mengikuti pelatihan sehingga produktivitas kerja yang sebelum nya tidak tercapai bisa tercapai dan hasil kerja yang didapatkan lebih baik setelah mengikuti pelatihan dibandingkan sebelumnya. Hal ini didukung oleh penelitian terdahulu Nadia Elviera Fiolita (2017) yang menyatakan bahwa adanya perbedaan antara sebelum pelatihan modul 2000 dengan sesudah pelatihan modul 2000 yang menyatakan bahwa produktivitas kerja karyawan sesudah mengikuti pelatihan jauh lebih baik dibandingkan sebelumnya. Perbedaan itu dilihat dari hasil pekerjaan yang dicapai jauh lebih baik. Auto 2000 Raden Intan Bandar Lampung selalu berupaya untuk meningkatkan produktivitas kerja karyawanya dan bertanggung jawab atas pekerjaan yang dibebankan terhadap karyawanya.

Alasan ini diperkuat oleh teori yang dikemukakan Bandura dan Wood (1989) menyatakan bahwa self-efficacy memiliki peran utama dalam proses pengaturan melalui motivasi individu dan pencapaian kerja yang sudah ditetapkan. Pertimbangan dalam self-efficacy juga menentukan bagaimana usaha yang dilakukan orang dalam melaksanakan tugasnya dan berapa lama waktu yang dibutuhkan untuk menyelesaikan tugas tersebut. Diperkuat oleh teori McClelland dikenal tentang teori kebutuhan untuk mencapai kebutuhan seseorang akan prestasi. Murray sebagaimana dikutip oleh Winardi merumuskan kebutuhan akan prestasi tersebut sebagai keinginan Melaksanakan sesuatu tugas atau pekerjaan yang sulit. Menguasai, memanipulasi, atau mengorganisasi obyek-obyek fisik, manusia, atau ide-ide melaksanakan hal-hal tersebut secepat mungkin dan seindependen mungkin, sesuai kondisi yang berlaku. 


\section{KESIMPULAN}

Berdasarkan hasil pengolahan dan analisis data, pengujian hipotesis, analisis dan pembahasan hasil penelitian tentang analisis perbandingan produktivitas kerja sales sebelum dan sesudah pelatihan pada Auto 2000 Raden Intan Bandar Lampung, maka dapat ditarik kesimpulan sebagai berikut :adanya perbedaan produktivitas kerja sales sebelum dan sesudah pelatihan pada Auto 2000 Raden Intan Bandar Lampung, dan menyatakan bahwa produktivitas kerja sales sesudah mengikuti pelatihan mengalami peningkatan jika dibandingkan produktivitas kerja sales sebelum pelatihan. Dengan adanya perbedaan tersebut, dapat diketahui bahwa belum bisa mencapai produktivitas yang telah ditetapkan oleh Auto 2000 Raden Intan Bandar Lampung. Hal ini dikarenakan masih kurangnya pemahaman karyawan terhadap pelatihan kerja yang diberikan, sehingga berakibat pada produktivitas yang dihasilkan belum dapat mencapai target yang telah ditetapkan oleh Auto 2000 Raden Intan Bandar Lampung.

\section{DAFTAR PUSTAKA}

Aryani, D., \& Rosinta, F. (2010). Pengaruh kualitas layanan terhadap kepuasan pelanggan dalam membentuk loyalitas pelanggan. Jurnal Ilmu Administrasi Dan Organisasi, 17(2), 114-126.

Aditya, M. R., \& Rahardja, E. (2015). Pengaruh Pelatihan Dan Lingkungan Kerja Terhadap Produktivitas Kerja Karyawan (Studi Pada PT. Primatexco Indonesia, Batang). Doctoral dissertation, Fakultas Ekonomika dan
Bisnis.

Claudia Munawar, M. A. R. S. H. A., \& Kuncoro, E. A. (2012). Analisis Pengaruh Rekrutmen Dan Pelatihan Kerja Karyawan Terhadap Produktivitas Kerja Karyawan Di Petrochina International Jabung Ltd. Doctoral dissertation, BINUS.

Dunggio, M. (2013). Semangat dan disiplin kerja terhadap produktivitas kerja karyawan pada PT. Jasa Raharja (Persero) cabang sulawesi utara. Jurnal EMBA: Jurnal Riset Ekonomi, Manajemen, Bisnis dan Akuntansi, 1(4).

Effi, D., \& Nisa, M. (2003). Studi Tentang Produktivitas Kerja Karyawan Bagian" Sales" Di PT. Pangan Lestari Sidoarjo. Jurnal Ilmu Pertanian: Mapeta, 5(14), 34-41.

Raharjo, S., Paramita, D. P., \& Warso, M. (2016). Pengaruh kemampuan kerja, pengalaman dan pelatihan terhadap produktivitas kerja karyawan dengan kompetensi kerja sebagai variabel intervening. Journal of Management, 2(2), 1-13.

Fiolita, N . E (2017). Analisis Perbedaan Sebelum Dan Sesudah Pelatihan Modul 2000 Karyawan Pt. Fastfood Indonesia Tbk. Kfc Adityawarman. Surabaya

Fitriana, L. N., Benty, D. D. N., \& Sunandar, A. (2017). Perbedaan Produktivitas Kerja Guru Antara Yang Sudah Dan Belum Sertifikasi Pada Sekolah Menengah Pertama (Smp) Di Kota Malang. Skripsi Jurusan Administrasi 
Pendidikan- Fakultas Ilmu Pendidikan Sutrisno, E. (2011). Manajemen Sumber Um.

Nasution, Y., \& Wardhana, A. (2018).

Analisis Perbedaan Produktivitas

Karyawan Sebelum Dan Sesudah

Pelatihan Pada Pt. Bank Rakyat

Indonesia, Tbk Kantor Cabang Serui. $e$ -

Proceedings of Management, 5(3).

Priyastama, Romie (2017),Buku Sakti Kuasai SPSS .Yogyakarta. Start up

Ridha, M. (2012). Analisis faktor-faktor yang mempengaruhi sales skill pada surat kabar pekanbaru pos (Doctoral dissertation, Universitas Islam Negeri Sultan Syarif Kasim Riau).

Salinding, R. (2011). Analisis Pengaruh Pelatihan Terhadap Produktivitas Kerja Karyawan Pada PT. Erajaya Swasembada Cabang Makassar. Jurnal Manajemen, 8(1), 83-106.

Sanusi, Anwar. (2017) Metodologi Penelitian Bisnis . Salemba Empat

Sinaga, S. N., \& Farida, L. (2015). Pengaruh Kompetensi Dan Pemberian Insentif Terhadap Produktivitas Kerja Salesman (Kasus Distributor Mobil Toyota PT. Agung Automall Soekarno-Hatta Pekanbaru) Effect of competence and granat of incentive to work productivity salesman (Case distributor PT. Ag. Jurnal Online Mahasiswa (JOM) Bidang Ilmu Sosial dan Ilmu Politik, 2(2), 1-15.

Sugiyarto, S. (2017). Analisis pengaruh produktivitas tenaga kerja terhadap penjualan pt $3 m$ indonesia. Sekretari, $3(2), 1$ 
